\title{
Scandal touches HIV vaccine development in Japan
}

Promising Japanese research to develop a human immunodeficiency virus (HIV) vaccine has been overshadowed by a stock market scandal that could jeopardize future funding of the research. Allegations of stock price manipulation by the former president of a now-defunct computer software company, which was developing the HIV vaccine with a scientist at Yokohama City University, have left researchers at the university entangled in a messy financial scandal.

Tsutomu Matsuzaki, the former president of TSD, which went bankrupt in November 1993, is alleged to have made false statements about progress being made in the development of the vaccine to boost the company's share price. At a press conference held in August 1992 at the Tokyo Stock Exchange Building, Matsuzaki announced that clinical trials had started in Thailand and that he had set up a company there to develop the vaccine, according to the Security and Exchange Surveillance Commission. Matsuzaki was arrested last month, almost three years later, after the commission filed an official complaint with the Tokyo district prosecutor's office.

Matsuzaki is also alleged to have claimed that TSD had signed a joint research agreement with a Medical Research Institute in Russia. The announcement was reportedly made at a press conference held five days before refunding was due on convertible bonds worth $¥ 4.7$ billion (US\$55 million). Following the announcement, TSD's share price rose from approximately $¥ 2,400$ to $¥ 2,800$, which led many investors who bought the bonds for $¥ 2,700$ to convert them into company stock at a reasonable profit.

The stock price of the company then rocketed, reaching a high of $¥ 3,650$ in September of that year. As a result, the company is alleged to have reduced its refunding burden by $¥ 1.5$ billion (US\$17.6 million). Clinical trials, however, did not take place.

In late 1992, Kenji Okuda a professor in the Department of Bacteriology at Yokohama City University School of Medicine, who was developing the vaccine for TSD, applied to the university's ethics committee for permission to proceed to clinical trials. Okuda is reported to have requested permission to test the safety and efficacy of a synthetic peptide antigen on a few healthy members of his research group but was turned down because of insufficient animal data.

Set up in 1972, TSD expanded rapidly during Japan's so-called bubble economy period of the 1980s, at which time the company diversified considerably. In addition to joining the highly competitive international race to develop and manufacture a commercially viable HIV vaccine, the company had tried to set up a university in Yokosuka, just outside Tokyo, and had real estate interests in the United States.

There are no suggestions of impropriety by Okuda but some critics question his judgement in getting involved with a company like TSD, which had no experience in the area of vaccine development, and they blame the isolated environment of Japanese universities for the naivete that led him into this situation.

"I will look carefully for a proper pharmaceutical company in the future," says Okuda. He is, however, unhappy about the way the Japanese press has reported the case and is concerned that it might hamper his chances of receiving future funding.

Japanese pharmaceutical companies are very conventional and are often reluctant to become involved with anyone associated with scandal, however remote. But Okuda is determined to continue with the same line of research (Nature Medicine 1, $681-685 ; 1995)$, and says that, if necessary, he will use his own personal funds. He and his colleagues are looking into the possibility of testing their candidate vaccine on chimpanzees in the United States later this year.

RICHARD NATHAN Tokyo
Clinical research and the need for follow-up

There is a need to examine how people who participate in clinical research receive follow-up once the research is complete, according to a report to be released this month by the US National Institutes of Health (NIH). The finding emerged from a survey of clinical trials funded by the NIH, which was conducted by Wendy Baldwin, deputy director for extramural research at the NIH.

The survey was prompted by last year's public outcry following revelations of problems with the data monitoring procedures in the tamoxifen breast cancer prevention trial run by the National Surgical Adjuvant Breast and Bowel Project (NSABP) of the University of Pittsburgh, and of five deaths in 1993 in the trial testing fialuridine as a treatment for hepatitis B.

The survey selected 140 of the 470 phase III (efficacy) clinical trials sponsored by the NIH. The recommendation to look further at patient follow-up arises, says Baldwin, because of the need to balance the patient's confidentiality against the need to make contact, perhaps years after the trial has ended, if a latent problem with the experimental therapy arises.

Also of particular interest to the NIH was the question of whether the trials all had data monitoring and safety boards in place. These boards can recommend that a trial be halted if there are safety problems or if results show that the experimental therapy is efficacious enough to be in general clinical use. Although, the NSABP did not have such a board, Baldwin says the survey shows that they are present more often than not.

The report also highlights the need to address the issues of who owns clinical trial data and exactly what information can be revealed.

Information from the survey will now feed into a panel on clinical research established by Harold Varmus, the director of the NIH (see Nature Medicine 1, 496; 1995). That panel met for the first time last month.

Helen Gavaghan Washington, $D C$ 